УДК 633.85:631.51.021: 631.8(477.7)

DOI https://doi.org/10.32848/agrar.innov.2021.8.4

\title{
ВПЛИВ ОСНОВНОГО ОБРОБІТКУ ҐРУНТУ НА ЩІЛЬНІСТЬ ТА ПОЖИВНИЙ РЕЖИМ ҐРУНТУ ПІД ЧАС ВИРОЩУВАННЯ РІПАКУ ОЗИМОГО
}

\author{
ГАРО I.M. - пошукач \\ http://orcid.org/0000-0003-1846-9483 \\ Миколаївський національний аграрний університет \\ ГАМАЮНОВА В.В. - доктор сільськогосподарських наук, професор \\ http://orcid.org/0000-0002-4151-0299 \\ Миколаївський національний аграрний університет
}

Постановка проблеми. Відомо, що оптимальні умови для життєдіяльності рослин створюються за відповідної щільності ґрунту, яка впливає на вміст у ньому вологи та повітря. Від щільності ґрунту залежить здатність його поглинати і утримувати вологу, забезпечувати іiі ефективне використання рослинами, а також поживними речовинами й повітрям. Це питання $€$ виключно важливим для всіх сільськогосподарських культур, зокрема і ріпаку озимого.

Аналіз останніх досліджень і публікацій. В останні роки в землеробській галузі швидко зростає енергоозброєність сільського господарства, що створює достатньо широкі можливості для інтенсивності обробітку ґрунту. Проте досвід і практика засвідчують, що в багатьох випадках з посиленням інтенсивності обробітку все частіше мають місце негативні наслідки. Зростають витрати на його виконання, які не завжди супроводжуються підвищенням урожайності, пришвидшується мінералізація гумусу, ґрунт розпилюється, зменшується його стійкість проти ерозії. Дослідженнями встановлено, що кожен прохід трактора і ґрунтообробних знарядь призводить до переущільнення ґрунту, що може негативно позначатись на якості наступних операцій з обробітків та врожайність сільськогосподарських культур [1].

За даними ряду авторів, наприклад, тривале застосування мілкої оранки, безполицевого обробітку і особливо дискування сприяє диференціації орного шару за твердістю і щільністю. Як правило, ці показники в шар ґрунту 0-10 см зменшуються, а у шарах 10-20 і 20-30 см порівняно з оранкою збільшуються.

Теоретичною основою мінімізації обробітку слугують досягнення в галузі агрофрізики ґрунту. У багатьох випадках та залежно від умов і факторів вирощування рівноважна щільність не виходить за межі оптимальної, а розпушування ґрунту не завжди здатне сприяти збереженню в ньому вологи [2; 3]. Загальновизнаною можна вважати думку, що надмірна щільність грунту погіршує його водний і повітряний режими, стає механічною перешкодою на шляху оптимального розвитку кореневої системи рослин.

В останні роки проведено багато досліджень щодо вивчення реакції сільськогосподарських культур на щільність орного шару ґрунту. Ще набагато раніше І.Б. Ревут, узагальнюючи велику кількість матеріалів даного спрямування, робить висновок про те, що реакція рослин на щільність ґрунту носить зональний характер і залежить від особливостей ґрунтової відміни [4].
Мета. Використовуючи щільність як показник діагностики для застосування того чи іншого способу обробітку ґрунту, рекомендується порівнювати наявну рівноважну щільність для даного типу ґрунту і оптимальну для певного виду рослин. Невідповідність цих величин вказує на необхідність добору виду і глибини обробітку ґрунту, заходи і способи якої повинні відповідати біологічним особливостям культури. Отож було прийнято рішення дослідити ці питання за вирощування ріпаку озимого.

Матеріали та методика досліджень. Упродовж 2012-2015 рр. проведено дослідження з культурою ріпаку озимого сорту Чемпіон України в умовах СТОВ «Зоря» Черкаського району Черкаської області. Грунтова відміна - чорнозем звичайний середньосуглинковий. Вміст гумусу в орному шарі грунту в середньому складає 3,16\%, забезпеченість рухомими сполуками азоту 26,2 мг/кг ґрунту (середній вміст), фросфору - 48,4 мг/кг ґрунту (підвищений вміст).

Погодні умови в роки вирощування ріпаку озимого дещо різнились і особливо за кількістю опадів, проте були типовими для зони проведення досліджень.

Залежно від заходу і глибини основного обробітку ґрунту в основні періоди вегетації рослин ріпаку озимого визначали щільність складення грунту (за методом ріжучого кільця), вміст нітратів (за методом ГрандвальЛяжу), рухомого фоссрору (за методом Мачигіна).

Результати досліджень. Нами було проведено визначення щільності орного шару ґрунту за двох різних способів його основного обробітку, результати яких наведено в таблиці 1. Щільність складення 0-30 см шару ґрунту після збирання попередника ріпаку озимого коли-

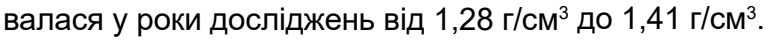

За результатами проведення основного обробітку ґрунту щільність у всіх варіантах досліду зменшилася, однак величина зміни цього показника більшою мірою залежала від способу обробітку, а не його глибини. Більш рихлий стан ґрунту забезпечувала оранка. У середньому щільність 0-30 см шару ґрунту у варіанті оранки на 25-27 см у фазу сходів ріпаку склала 1,16 г/ $\mathrm{cm}^{3}$. На ділянках, оброблених дисковою бороною на глибину 12-14 см, вона була більшою порівняно з оранкою

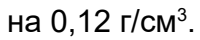

Під впливом осінньо-зимових опадів спостерігали ущільнення ґрунту. Причому це відбувалося в усіх варіантах незалежно від способу і глибини основного обробітку. Визначено, що більшою мірою до ущільнення схильний верхній (0-10 см) шар ґрунту. У середньому 
до фрази стеблування у варіанті з оранкою 0-30 см шар

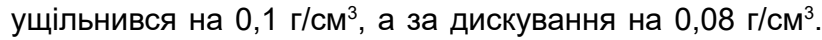
Орний шар ущільнюється в осінньо-зимовий і ранньовесняний періоди.

Динаміка щільності ґрунту на посівах ріпаку озимого залежно від способу його обробітку

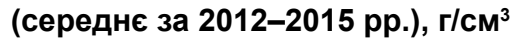

\begin{tabular}{|c|c|c|}
\hline \multirow{2}{*}{ Шар ґрунту, см } & Обробіток ґрунту \\
\cline { 2 - 3 } & оранка & дискування \\
\hline \multicolumn{3}{|c|}{ Сходи } \\
\hline $0-10$ & 1,05 & 1,08 \\
\hline $10-20$ & 1,16 & 1,34 \\
\hline $20-30$ & 1,28 & 1,41 \\
\hline $0-30$ & 1,16 & 1,28 \\
\hline \multicolumn{3}{|c|}{ Стеблування } \\
\hline $0-10$ & 1,12 & 1,24 \\
\hline $10-20$ & 1,30 & 1,39 \\
\hline $20-30$ & 1,35 & 1,44 \\
\hline $0-30$ & 1,26 & 1,36 \\
\hline \multicolumn{3}{|c|}{ Цвітіння } \\
\hline $0-10$ & 1,24 & 1,25 \\
\hline $10-20$ & 1,39 & 1,41 \\
\hline $20-30$ & 1,41 & 1,44 \\
\hline $0-30$ & 1,35 & 1,37 \\
\hline \multicolumn{3}{|c|}{ Повна стиглість насіння } \\
\hline $0-10$ & 1,14 & 1,17 \\
\hline $10-20$ & 1,23 & 1,40 \\
\hline $20-30$ & 1,26 & 1,44 \\
\hline $0-30$ & 1,21 & 1,34 \\
\hline
\end{tabular}

Незначне ущільнення ґрунту у всіх варіантах досліду тривало до фази цвітіння ріпаку озимого, що частково відбувалося й під впливом атмосферних опадів. У цей період спостерігали деяке нівелювання відмінностей у щільності складення ґрунту за варіантами досліду.

Таким чином, проведення оранки під посіви ріпаку озимого сприяє зменшенню щільності ґрунту, що в свою черг оптимізує умови життєдіяльності рослин - інтенсифікує розвиток кореневої системи, покращує водний, поживний та повітряний режими ґрунту.

Основним джерелом елементів живлення для рослин $\epsilon$ ґрунт. Рівень родючості ґрунту $є$ визначальним фрактором одержання високих і сталих рівнів урожаїв сільськогосподарських культур. Це явище не є постійним, у деяких випадках воно динамічне, а в оброблюваних ґрунтах ця динаміка простежується безперервно. Численні наукові дані щодо впливу тривалого застосування різних систем основного обробітку на поживний режим ґрунту $€$ достатньо суперечливими. Залежить це, зокрема, від рівня забезпеченості ґрунту NPK і внесення добрив.

Порівняно з щорічною оранкою довготривалий безполицевий обробіток призводить до збільшення вмісту рухомого фосфрору і обмінного калію у верхньому орному шарі та значного зменшення його в нижніх горизонтах [5].

3 метою усунення диференціації орного шару за родючістю та підвищення його мікробіологічної актив- ності ряд дослідників дійшли висновку про доцільність періодичного чергування полицевих і безполицевих обробітків ґрунту [6; 7].

Ріпак озимий розвиває велику кореневу систему та фрормує й значну надземну масу, тому він засвоює з ґрунту багато поживних речовин. Для створення однієї тонни насіння з відповідною кількістю біомаси він виносить із ґрунту: азоту - 45-80 кг, фросфрору - 18-40 кг, калію - 25-100 кг, кальцію - 30-150 кг, магнію - 5-15 кг, сірки - 30-45 кг [8].

Поживний режим ґрунту багато в чому залежить від способу основного обробітку ґрунту. Оранка порівняно з дискуванням значно посилює мінералізацію органічної речовини і збільшує ефективність використання елементів мінерального живлення, хоча при цьому внаслідок активної нітрифікації, а в подальшому денітрифікації, можуть відбуватись і втрати сполук азоту [9].

Про це повідомляють і за результатами досліджень у сівозміні з проведення основного обробітку ґрунту на зрошуваних землях з обертом пласта [10]. За безвідвальних способів обробітків грунту цей процес в основному протікає в анаеробних умовах, що більшою мірою сприяє збагаченню ґрунту поживними речовинами.

Нашими дослідженнями підтверджено певний вплив способу і глибини основного обробітку ґрунту під ріпак озимий на його поживний режим.

Проведені нами дослідження в умовах природного зволоження показали, що вміст нітратів у ґрунті змінювався протягом вегетаційного періоду ріпаку озимого (табл. 2).

Необхідно звернути увагу, що незалежно від способу основного обробітку ґрунту максимальний вміст нітратів визначено у фазу утворення весняної розетки. У подальшій вегетації, а саме у фазу цвітіння, спостерігали суттєве зниження їх кількості у всіх досліджуваних шарах ґрунту, що співпадає з максимальним використанням сполук азоту, адже саме у цей міжфазний період вегетації найбільш інтенсивно наростає надземна біомаса рослин ріпаку озимого, що встановлено нашими дослідженнями [11]. У фазу молочної стиглості насіння через відмирання дрібних коренів, їх часткової мінералізації та пожовтіння листків відбувається незначне підвищення вмісту нітратів у шарах ґрунту 0-30 та 30-50 см порівняно з визначенням їх у попередній період відбору зразків.

Проведення оранки сприяло лише деякому посиленню процесів нітрифікації і мало незначну тенденцію до дещо більшого накопичення нітратів у досліджуваних шарах ґрунту порівняно з дискуванням. У цьому варіанті вміст нітратів в основні періоди вегетації рослин ріпаку озимого, наприклад, у шарі ґрунту 0-50 см лише на 0,2-1,6 мг/кг ґрунту перевищував їх кількість порівняно з посівами, де проводили дискування. Тобто можна вважати, що різниці між вмістом їх за різних способів і глибиною обробітку ґрунту не встановлено.

Пояснюється це, очевидно тим, що у фазу весняної розетки більша частина нітратів витрачалась на відновлення загиблої вегетативної маси і тому в ґрунті їх вміст дещо зменшувався. У фазу цвітіння рослини формували потужну надземну біомасу, що й посприяло 
Вплив основного обробітку ґрунту на вміст нітратів під посівами ріпаку озимого

(середнє за 2012-2015 рр.), мг/кг ґрунту

\begin{tabular}{|c|c|c|c|c|}
\hline \multirow{2}{*}{ Шар грунту, см } & \multicolumn{5}{|c|}{ Періоди вегетації рослин рослин } \\
\cline { 2 - 5 } & сходи & весняна розетка & цвітіння & молочна стиглість насіння \\
\hline \multicolumn{5}{|c|}{ Дискування на 12-14 см } \\
\hline $0-30$ & 22,9 & 28,6 & 11,1 & 15,7 \\
\hline $30-50$ & 11,2 & 14,7 & 4,7 & 12,3 \\
\hline $0-50$ & 18,2 & 23,0 & 8,5 & 16,1 \\
\hline \multicolumn{5}{|c|}{ Оранка на 25-27 см } \\
\hline $0-30$ & 23,4 & 30,8 & 2,7 & 12,7 \\
\hline $30-50$ & 10,9 & 15,3 & 5,5 & 9,8 \\
\hline $0-50$ & 18,4 & 24,6 &
\end{tabular}

значному виносу рухомого азоту з ґрунту. До кінця вегетації споживання азоту рослинами зменшується, і вміст нітратів у ґрунті за варіантами досліду щодо способів та глибин обробітку вирівнюється.

Фосфору рослини усіх сільськогосподарських культур і ріпаку зокрема виносять значно менше, ніж азоту. Однак забезпеченість рослин фоссфором у різних ґрунтових умовах потребує не меншої уваги, ніж азотом, який для більшості типів ґрунтів знаходиться у першому мінімумі [12]. На відміну від азоту, ґрунтів, багатих на вміст фоссфору, в природі практично не існує. Особливо важливою обставиною, яка ускладнює живлення рослин фосфором, $є$ низька його розчинність, недостатня рухомість, важка доступність рослинам фоссфорних сполук ґрунту. Фосфор, що внесли в ґрунт у формі розчинних мінеральних добрив, досить швидко переходить в слабко- і важкорозчинні форми, за взаємодії перш за все 3 карбонатами кальцію він утворює тризаміщений фосфрат кальцію, який за нейтрального середовища ґрунтового розчину слабко розчиняється. Це досить сильно залежить від зволоження ґрунту та його мікробіологічної діяльності [13-15].

Добре відомо, що доступність рослинам фосфатів у ґрунті залежить, перш за все, від оптимізації мікробіо- логічної активності ґрунту, тобто від забезпечення умов відповідної аерації і підвищення вологозабезпеченості шляхом структуроутворення і розпушування ґрунту, внесення органічних добрив [16; 17]. Особливість забезпечення рослин фосфором за різних способів і глибин обробітку ґрунту пов'язана з перерозподілом рухомих фоссратів у межах шару, який обробляють [18].

Зокрема, акумуляція рухомого фоссрору в поверхневому 0-10 см шарі ґрунту пов'язана з локалізацією у ньому добрив, а також із тим, що фросфати здатні контактувати з меншим об'ємом ґрунту, внаслідок чого меншою мірою фріксуються абсорбуючим комплексом [19].

Гетерогенність орного шару ґрунту у відношенні до фоосфору ряд дослідників вважають позитивним явищем, тому що за цього покращуються умови живлення, особливо на початку вегетації рослин, коли саме з верхнього шару грунту рослини використовують у 10 разів більше фоссрору, ніж із нижнього.

Саме задля задоволення потреб рослин у фосфорі в критичний період перед сівбою вносять $\mathrm{P}_{2} \mathrm{O}_{5}$ [20].

Нашими дослідженнями визначено, що на початку вегетації ріпаку в шарі ґрунту 0-50 см більша кількість рухомого фросфору містилася на посівах, де проводили оранку на 25-27 см (рис. 1).

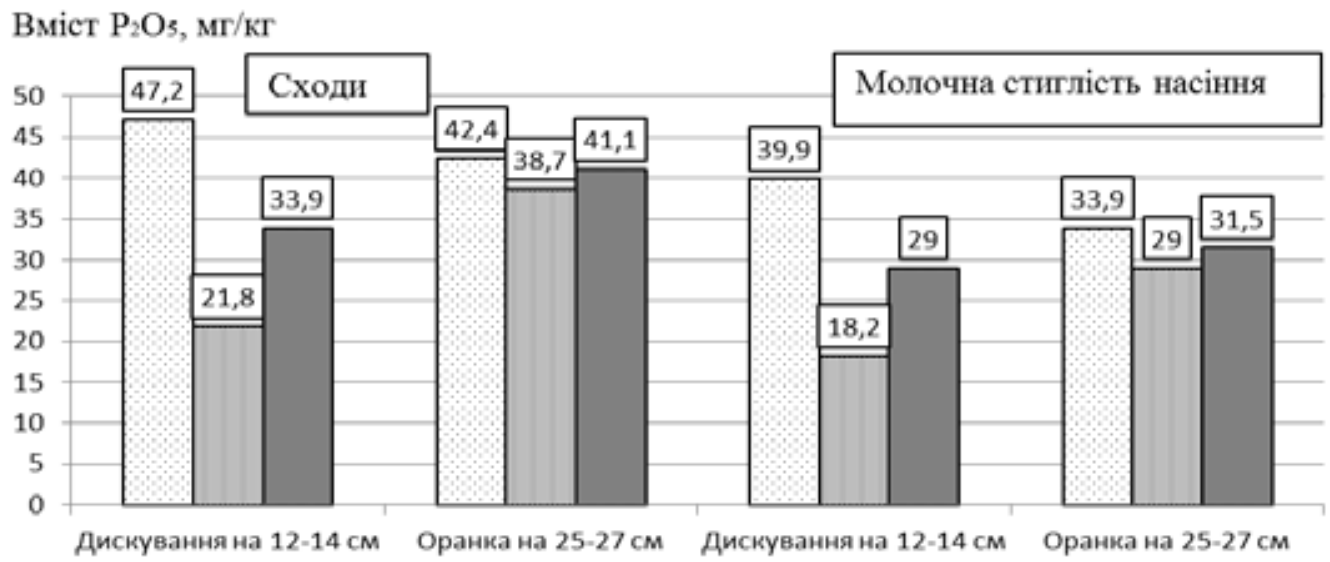

ㅁㅁ문

Рис. 1. Вплив способу і глибини основного обробітку ґрунту на вміст $P_{2} O_{5}$ під посівами ріпаку озимого (середнє за 2012-2015 рр.), ме/ке ґрунту 
У варіантах із дискуванням цей показник був меншим на 1,72 мг/кг ґрунту. У фразу молочної стиглості насіння відмінності у вмісті рухомого фоссфору в ґрунті за всіх заходів і глибини його обробітку були практично неістотними.

Найбільш відчутним зниження вмісту фосфрору за вегетацію було визначено у варіанті досліду, де проводили оранку - 9,6 мг/кг ґрунту, проте воно практично не різнилось відносно варіанта з дискуванням. Незалежно від способу і глибини основного обробітку ґрунту використання фоссфору рослинами ріпаку озимого (67\%) відбувалося переважно з шару 0-30 см і лише 23\% - із глибшого шару ґрунту - 30-50 см.

Висновки. Дослідженнями, проведеними впродовж 2012-2015 рр., встановлено, що під впливом способу і глибини основного обробітку ґрунту під час вирощування ріпаку озимого щільність ґрунту впродовж вегетації культури дещо змінювалася. У період сходів у шарі ґрунту 0-30 см за проведення оранки на 25-27 см вона

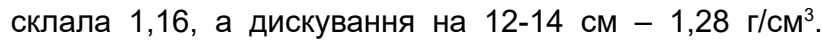
У фазу повної стиглості зерна зазначені показники від-

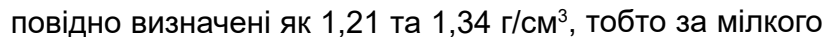
обробітку ґрунту порівняно з оранкою ґрунт мав більшу

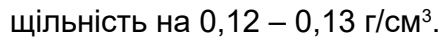

Дослідженнями визначено, що більшої щільності зложення ґрунт набуває у подальші періоди вегетації - фрази цвітіння та стеблування за фоном дискування у шарах 10-20 і 20-30 см. Досліджувані способи обробітку ґрунту ще меншою мірою впливали на вміст нітратів у ґрунті, причому як на початку, так і після завершення вегетації культури різниця між дискуванням та оранкою склала лише 0,2-0,3 мг/кг ґрунту (вона була в межах помилки досліду) за незначної тенденції переваги оранки. Проте значно більшою різниця оранки порівняно з дискуванням визначена у фазу цвітіння - у шарі ґрунту 0-50 см нітратів містилося 8,5 мг/кг по фону дискування та 9,8 мг/кг відповідно - за проведення оранки.

Ще меншою мірою залежно від способу і глибини основного обробітку ґрунту змінювався вміст у шарах ґрунту рухомого фосфору. Так, на період молочної стиглості насіння ріпаку озимого у шарі 0-50 см цього елементу містилося 29,0 мг/кг за дискування і 31,5 мг/кг - за проведення оранки. Разом із тим у шарі грунту 0-30 см як на початку, так і після завершення вегетації культури, за фроном дискування $\mathrm{P}_{2} \mathrm{O}_{5}$ містилося дещо більше, ніж за оранки, що очевидно пояснюється акумуляцією рухомих фоосфатів у верхніх шарах грунту.

\section{СПИСОК ВИКОРИСТАНОÏ ЛІТЕРАТУРИ:}

1. Гордієнко В.П. Мінімалізація обробітку ґрунту в польовій сівозміні. Збірник наукових праць, присвячений 100-річчю з дня народження С.С. Рубіна. Умань : УСГА, 2000. 464 с.

2. Медведев В.В., Лактионова Т.Н., Донцова Л.В. Водные свойства почв Украины и влагообеспеченность сельскохозяйственных культур. Харьков : Апостроф, 2011. 224 c.

3. Chang C., Lindwall W. Effect of long-term minimum tillage practices on some physical properties of a chernozemic clayloam. Canad. I. Soil Sc., 1989. P. 443-449.
4. Ревут И.Б., Соколовская И.А., Васильев А.М. Структура и плотность почвы - основные параметры кондиционирующие почвенные условия жизни растений. Ленинград : Гидрометеоиздат, 1971. С. 54-125.

5. Погромська Я. Вплив систем удобрення на забезпеченість чорнозему звичайного рухомими формами NPK залежно від способів його обробітку. Вісник Львівського національного аграрного університету. Агрономія. 2019. № 23. С. 212-221. URL : https://doi.org/10.31734/agronomy2019.01.212.

6. Гордієнко В.П., Бодня В.І. Вплив тривалого застосування різних систем удобрення у обробітку грунту в сівозміні на урожайність ярого ячменю. Наукові праці Полтавської державної аграрної академії. 2005. № 4(23). С. 94-100.

7. Сайко В.Ф., Малієнко А.М. Системи обробітку грунту в Україні. Київ : ВД «ЕМКО», 2007. 44 с.

8. Лихочвор В.В., Проць Р.Р. Ріпак. Львів : НВФ Українські технології, 2005. 88 с.

9. Małecka, I., Blecharczyk, A., Sawinska, Z., Dobrzeniecki, $T$. The effect of various long-term tillage systems on soil properties and spring barley yield. Turkish Journal of Agriculture and Forestry. 2012. 36, 217-226. doi: 10.3906/tar-1104-20.

10. Марковська О.Є. Наукове обґрунтування агроекологічних та технологічних заходів у сівозмінах на зрошуваних землях Південного Степу України : автореф. дис. ... д-ра с.-г. наук : 06.01.02. Херсон, 2018. 43 с.

11. Гамаюнова В.В., Гаро І.М. Урожайність і якість насіння ріпаку озимого залежно від обробітку грунту, строку та способу сівби в умовах Лісостепу України. Вісник ЖНЕАУ. Житомир, 2017. № 1(58), Т. 1. С. 49-57.

12. Гамаюнова В.В. Зміна родючості грунтів південного Степу України під впливом добрив та підходи до їх ефрективного застосування у сучасному землеробстві. Агрохімія і грунтознавство: спец. випуск до IX з їзду УТГА (30 червня - 4 липня 2014 р., м. Миколаїв). Харків, 2014. Книга 1. С. 38-47.

13. Bogužas V., Sinkevičienè A., Romaneckas K., Steponavičienè V., Butkevičienè L. M. The impact of tillage intensity and meteorological conditions on soil temperature, moisture content and $\mathrm{CO} 2$ efflux in maize and spring barley cultivation. Zemdirbyste-Agriculture. 2018, 307-314. doi: 10.13080/z-a. 2018.105.039.

14. Чайковська Л.О., Гамаюнова В.В. Фосфратмобілізуючі бактерії та їх вплив на продуктивність рослин. Зб. наук. праць Уманського ДАУ (спеціальний випуск). Умань : Уманський ДАУ, 2003. С. 220-226.

15. Пілюк Я.Є., Белавський В.М. Особливі аспекти вирощування озимого ріпаку. Сучасні технології рослинництва в Білорусі. Мінськ : Міністерство фрінансів ІВЦ, 2005. С. 134-146.

16. Примак І.Д., Панченко О.Б. Вплив механічного обробітку грунту та удобрення у спеціалізованій зернопросапній сівозміні Центрального Лісостепу України на агрофрізичні властивості чорнозему типового. Наукові доповіді Національного університету біоресурсів і природокористування України. 2015. № 6. URL : http://nbuv.gov.ua/UJRN/Nd_2015_6_11.

17. Hamajunova U., Hlushko T., Honenko L. Presevation of soil fertility as a basis for improving the efficiency of management in the southern Steppe of Ukraine. Scientific development and achievements-Sciemcee. London, 2018. Vol. 4. P. 13-27. 
18. Конишев А.А., Конишева Е.Х. Погодные условия и выбор обработки почвы. Земледелие. 2007. С. 6-12.

19. Шикула М.К., Гнатенко А.Ф. Фосфорний стан еродованого чорнозему в залежності від технологій вирощування сільськогосподарських культур. Вісник сільськогосподарські науки. 1985. № 10. С. 23-27.

20. Сдобников С. С. Обработка почвы и питание растений. Земледелие. 1980. № 8. С. 18-21.

\section{REFERENCES:}

1. Gordiyenko, V.P. (2000). Minimalizaciya obrobitku g'runtu $v$ pol'ovij sivozmini [Minimization of tillage in field crop rotation]. Zbirny'k naukovy' kh pracz', pry`svyacheny`j 100-richchyu z dnya narodzhennya S.S. Rubina - Collection of scientific works dedicated to the 100th anniversary of the birth of S.S. Rubin. Uman': USGA, 464 [in Ukrainian].

2. Medvedev, V.V., Lakty`onova, T.N., \& Donczova, L.V. (2011). Vodnie svojstva pochv Ukray'ni y’ vlagoobespechennost' sel'skokhozyajstvennikh kul'tur [Water properties of soils of Ukraine and moisture supply of agricultural crops]. Khar'kov: Apostrof, 224 [in Ukrainian].

3. Chang, C., \& Lindwall, W. (1989). Effect of long-term minimum tillage practices on some physical properties of a chernozemic clayloam. Canad. I. Soil Sc., 443-449 [in English].

4. Revut, Y'.B., Sokolovskaya, Y'.A., \& Vasy'lev, A.M. (1971). Struktura y’ plotnost' pochvy - osnovnye parametry kondy'cy'ony'ruyushhy'e pochvennie uslovy'ya zhy'zny' rasteny'j [Soil structure and density are the main parameters for conditioning soil conditions of plant life]. L.: Gy`drometeoy zdat, 54-125 [in Russian].

5. Pogroms`ka, Ya. (2019). Vply`v sy`stem udobrennya na zabezpechenist' chornozemu zvy'chajnogo rukhomy 'my` formamy' NPK zalezhno vid sposobiv jogo obrobitku [The infusion of fertilization systems for the safety of black soil with ruhomous forms of NPK is deposited as a method of processing]. Visny'k L'vivs'kogo nacional 'nogo agrarnogo universy'tetu. Agronomiya Bulletin of Lviv National Agrarian University. Agronomy, 23, 212-221. https://doi.org/10.31734/agronomy2019. 01.212 [in Ukrainian].

6. Gordiyenko, V.P., \& Bodnya, V.I. (2005). Vply` try valogo zastosuvannya rizny`kh sy`stem udobrennya u obrobitku gruntu $v$ sivozmini na urozhajnist' yarogo yachmenyu [The effect of long-term use of different fertilizer systems in tillage on crop rotation on the yield of spring barley]. Naukovi praci Poltavs koyi derzhavnoyi agrarnoyi akademiyi - Scientific works of Poltava State Agrarian Academy, 4 (23), 94-100 [in Ukrainian].

7. Sajko, V.F., \& Maliyenko, A.M. (2007). Sy`stemy obrobitku gruntu $v$ Ukrayini [Tillage systems in Ukraine]. Ky`yiv: VD «EMKO», 44 [in Ukrainian].

8. Lyhochvor, V.V., \& Procz', R.R. (2005). Ripak [Rapeseed] L'viv: NVF Ukrayins'ki texnologiyi, 88 [in Ukrainian].

9. Małecka, I., Blecharczyk, A., Sawinska, Z., \& Dobrzeniecki, T. (2012). The effect of various long-term tillage systems on soil properties and spring barley yield. Turkish Journal of Agriculture and Forestry. 36, 217-226. doi: 10.3906/tar-1104-20 [in English].

10. Markovs`ka, O.Ye. (2018). Naukove obg'runtuvannya agroekologichny'kh ta tekhnologichny'kh zakhodiv u sivozminakh na zroshuvany'kh zemlyakh Pivdennogo Stepu Ukrayiny` [Scientific substantiation of agroecological and technological measures in crop rotations on irrigated lands of the Southern Steppe of Ukraine]. Extended abstract of Doctor's thesis. Kherson [in Ukrainian].

11. Gamayunova, V.V., \& Garo, I.M. (2017). Urozhajnist' i yakist' nasinnya ripaku ozy 'mogo zalezhno vid obrobitku gruntu, stroku ta sposobu sivby' $v$ umovakh Lisostepu Ukrayiny' [Yield and quality of winter rape seeds depending on tillage, timing and method of sowing in the Forest-Steppe of Ukraine]. Visny 'k ZhNEAU Bulletin of ZHNEAU, 1 (58), 1, 49-57 [in Ukrainian].

12. Gamayunova, V.V. (2014). Zmina rodyuchosti gruntiv pivdennogo Stepu Ukrayiny' pid vply'vom dobry`v ta pid khody' do yikh efekty 'vnogo zastosuvannya u suchasnomu zemlerobstvi [Changing the fertility of soils of the southern steppe of Ukraine under the influence of fertilizers and approaches to their effective use in modern agriculture]. Agrokh imiya $i$ gruntoznavstvo - Agrochemistry and soil science. Kharkiv. Kny'ga 1, 38-47 [in Ukrainian].

13. Bogužas, V., Sinkevičienè, A., Romaneckas, K., Steponavičienè, V., \& Butkevičienè, L.M. (2018). The impact of tillage intensity and meteorological conditions on soil temperature, moisture content and $\mathrm{CO} 2$ efflux in maize and spring barley cultivation. ZemdirbysteAgriculture, 307-314. doi: 10.13080/z-a. 2018.105.039 [in English].

14. Chajkovs`ka, L.O., \& Gamayunova, V.V. (2003). Fosfatmobilizuyuchi bakteriyi ta yikh vply'v na produkty 'vnist' rosly'n [Phosphate-mobilizing bacteria and their effect on plant productivity]. Zb. nauk. pracz' Umans kogo DAU - Coll. Science. works of Uman State Agrarian Universit. Uman`: Umans `ky`j DAU, 220-226 [in Ukrainian].

15. Pilyuk, Ya.Ye., \& Belavs`ky’j, V.M. (2005). Osobly`vi aspekty` vyroshhuvannya ozymogo ripaku. Suchasni tekhnologiyi roslynnycztva $v$ Bilorusi [Special aspects of growing winter rape. Modern crop technologies in Belarus]. Mins'k: Ministerstvo finansiv IVCz, 134-46 [in Ukrainian].

16. Pry`mak, I.D., \& Panchenko, O.B. (2015). Vply`v mekhanichnogo obrobitku gruntu ta udobrennya u specializovanij zernoprosapnij sivozmini Central'nogo Lisostepu Ukrayiny` na agrofizy`chni vlasty`vosti chornozemu typovogo [Influence of mechanical tillage and fertilizer in specialized grain plowing of the Central Forest-Steppe of Ukraine on agrophysical properties of typical chernozem]. Naukovi dopovidi Nacionalnogo universytetu bioresursiv i pry'rodokorystuvannya Ukrayiny - Scientific reports of the National University of Life and Environmental Sciences of Ukraine, 6. URL: http://nbuv.gov.ua/UJRN/Nd_2015_6_11[in Ukrainian].

17. Hamajunova, U., Hlushko, T., \& Honenko, L. (2018). Presevation of soil fertility as a basis for improving the efficiency of management in the southern Steppe of Ukraine. Scientific development and achievements-Sciemcee, 4, 13-27 [in English].

18. Kony`shev, A.A., \& Kony`sheva, E.X. (2007). Pogodnie uslovy ya y' vibor obrabotky' pochvi [Weather conditions and choice of tillage]. Zemledely'e - Agriculture, 6-12 [in Russian].

19. Shy`kula, M.K., \& Gnatenko, A.F. (1985). Fosforny`j stan erodovanogo chornozemu $v$ zalezhnosti vid texnologij vy`roshhuvannya sil’s 'kogospodars`ky`x kul`tur 
[Phosphorus state of eroded chernozem depending on the technologies of growing crops]. Visny'k sil's'kogospodars 'ki nauky - Bulletin of Agricultural Sciences, 10, 23-27 [in Ukrainian].

20. Sdobny kov, S.S. (1980). Obrabotka pochvi y py`tany`e rasteny`j [Soil cultivation and plant nutrition] Zemledely`e - Agriculture, 8, 18-21 [in Russian].

Гаро І.М., Гамаюнова В.В. Вплив основного обробітку ґрунту на щільність та поживний режим ґрунту під час вирощування ріпаку озимого

Мета. Метою досліджень передбачали визначити вплив способу і глибини основного обробітку ґрунту під сівбу ріпаку озимого на окремі його показники, зокрема на щільність складення та вміст рухомих сполук азоту і фросфору. Методи. Дослідження проводили на чорноземі звичайному середньосуглинковому в умовах Лісостепу України впродовж 2012-2015 рр. з ріпаком озимим сорту Чемпіон України. При проведенні досліджень використовували загальноприйняті методи, методики та ДСТУ. Досліджували вплив способу основного обробітку Ґрунту - оранки на 25-27 см та дискування на 12-14 см на щільність складення ґрунту, його поживний режим: вміст рухомих сполук азоту і фоосфору під час вирощування ріпаку озимого сорту Чемпіон України та їх сезонні зміни впродовж вегетації культури. Результати. За результатами проведених досліджень встановлено, що прийняті на вивчення способи і глибина основного обробітку ґрунту під ріпак озимий найбільшою мірою позначилися на такому показникові, як щільність складення ґрунту.

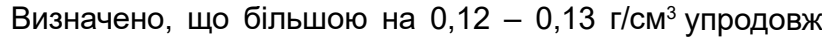
вегетації щільність грунту була за фоном дискування на 12-14 см порівняно з оранкою на 25-27 см. На вмісті рухомих форм азоту і фосфрору у шарах ґрунту 0-30, 30-50 та 0-50 см способи обробітку його як на початку, так і в кінці вегетації рослин ріпаку озимого практично не позначились не так істотно. Найбільшою кількість рухомих елементів живлення визначена на весняний період за істотного зменшення їх вмісту до фрази цвітіння. Спосіб і глибина обробітку ґрунту дещо впливала і на пошарове розміщення нітратів, хоча загалом у шарі ґрунту 0-50 см у середньому за роки досліджень їх вміст практично не різнився і мав лише тенденцію переваги за оранки на 20-25 см. Значно більшою мірою за шарами ґрунту вирізнявся вміст рухомого фосфору. За поверхневого обробітку ґрунту - дискування на 12-14 см порівняно 3 оранкою більше $\mathrm{P}_{2} \mathrm{O}_{5}$ містилося у шарі 0-30 см. За проведення оранки ж у підорному 30-50 см горизонті цього елементу визначено 29,0, а по фону дискування 18,2 мг/кг ґрунту. У розрахунковому 0-50 см шарі ґрунту кількість рухомого фоосфору була практично однаковою - 29,0 (дискування) та 31,5 мг/кг ґрунту (за оранки). У сезонній динаміці вміст рухомих елементів живлення незалежно від способу і глибини обробітку ґрунту зменшувався, а щільність складення, навпаки зростала. Висновки. Дослідженнями встановлено, що спосіб і глибина основного обробітку ґрунту під ріпак озимий, а саме оранка на 25-27 см та дискування на 12-14 см певною мірою впливали на щільність ґрунту і менше на вміст рухомих сполук азоту і фосфору за незначної переваги проведення у якості основного обробітку ґрунту оранки.

Ключові слова: ріпак озимий, спосіб основного обробітку ґрунту, вміст рухомих елементів живлення, щільність ґрунту.
Garo I.M., Gamajunova V.V. Influence of basic soil cultivation on the density and nutritional regime of soil during winter rape cultivation

Purpose. The purpose of the research was to determine the influence of the method and depth of basic soil cultivation under winter rape sowing on its individual indicators, in particular on the density and content of moving compounds of nitrogen and phosphorus. Methods. The research was carried out on the black earth of the usual medium-clay in conditions of the forest steppe of Ukraine for 2012-2015 years. with winter rape varieties Champion of Ukraine. When conducting research, generally accepted methods, techniques and DSTU were used. The influence on the basic soil cultivation - ploughing by $25-27 \mathrm{~cm}$ and disking by $12-14 \mathrm{~cm}$ on the density of soil composition, its nutritional regime: the content of moving compounds of nitrogen and phosphorus in the cultivation of winter rape Champion of Ukraine and their seasonal changes during the vegetation of the culture were investigated. Results. According to the results of the researches it is established that the methods taken for the study and depth of the main cultivation of rape rape have the greatest impact on such an indicator as the density of soil composition. It was determined that by $0.12-0.13 \mathrm{~g} / \mathrm{cm}^{3}$ during the growing season, the density of the soil was $12-14 \mathrm{~cm}$ in comparison with ploughing by $25-27 \mathrm{~cm}$. The content of moving forms of nitrogen and phosphorus in the soil layers $0-30,30-50$ and $0-50 \mathrm{~cm}$ methods of processing it both at the beginning and at the end of the vegetation of winter rapeseed plants did not affect much. The largest number of moving nutrients is determined for the spring period with a significant decrease in their content before the flowering phase. The method and depth of soil cultivation had some impact on the layered placement of nitrates, although in the soil layer $0-50 \mathrm{~cm}$ on average over the years of research, their content practically did not differ and had only a tendency of preference for ploughing by $20-25 \mathrm{~cm}$. Much more than layers of soil differed in the content of moving phosphorus. For surface tillage $12-14 \mathrm{~cm}$ disking compared to ploughing more P2O5 was contained in a layer of $0-30 \mathrm{~cm}$. For ploughing the same in the horseshoe $30-50 \mathrm{~cm}$ horizon of this element was determined 29.0, and on the background of disking $18.2 \mathrm{mg} / \mathrm{kg}$ of soil. In the calculated $0-50 \mathrm{~cm}$ layer of soil, the amount of moving phosphorus was almost the same 29.0 (disking) and $31.5 \mathrm{mg} / \mathrm{kg}$ of soil (per ploughing). In seasonal dynamics, the content of moving nutrients, regardless of the method and depth of soil cultivation, decreased, and the density of folding, on the contrary, increased. Conclusions. Studies have established that the method and depth of basic cultivation of the soil for winter rape, namely ploughing by $25-27 \mathrm{~cm}$ and disking by $12-14 \mathrm{~cm}$, to some extent, affected the density of the soil and less the content of moving compounds of nitrogen and phosphorus with little advantage as a basic tillage of tillage.

Key words: winter rape, method of basic soil cultivation, content of moving nutrients, soil density. 